\title{
Addition of microencapsulated soybean molasses to pasta formulations
}

\author{
Vanessa Sabrina Fagundes Batista ${ }^{1^{*}}$ (D) Graciele Lorenzoni Nunes ${ }^{1}$ \\ Andressa Fraton Moreira da Silva ${ }^{1}$ Gabriela Ilha Viegas ${ }^{1}$ Bruna Nichelle Lucas ${ }^{1}$ (i) \\ Juliano Smanioto Barin ${ }^{1}$ (i) Cristiano Ragagnin de Menezes ${ }^{1}$ (i) Claudia Severo da Rosa ${ }^{1}$ (D)
}

${ }^{1}$ Programa de Pós-graduação em Ciência e Tecnologia de Alimentos, Universidade Federal de Santa Maria (UFSM), 97105-900, Santa Maria, RS, Brasil. E-mail: vanessabatista.f@hotmail.com. *Corresponding author.

ABSTRACT: This study investigated the production of pasta with the addition of microencapsulated soybean molasses and its effect on the physicochemical, sensory, and microbiological characteristics and shelf life of the product. Three formulations were prepared, as follows: F1, control pasta; F2, pasta made with free extract; and F3, pasta made with soybean molasses microparticles, which were characterized in terms of their $\mathrm{pH}$, water activity, color measurements, sensory evaluation, microbiological characterization, and shelf life via determination of the phenolic compounds remaining during a 28 day storage. The cooked pasta containing the microparticles retained $25 \%$ of the original phenolics up to $14^{\text {th }}$ day of storage, meanwhile, the raw pasta presented $15 \%$ of the original phenolics up to the $21^{\text {st }}$ day of storage. Good sensory acceptability was observed for all pasta containing the microparticles, with no differences from the control pasta; however, pasta made with free extract was less accepted when compared to the other types. The addition of microparticles did not change the microbiological profile, pH, water activity, or color of the pasta.

Key words: sensory evaluation, phenolic, microcapsules, color.

Efeito da adição de microcápsulas do melaço de soja em massas alimentícias

RESUMO: Este trabalho teve como objetivo desenvolver massas alimentícias adicionadas de microcápsulas de melaço de soja e avaliar o efeito das microcápsulas sobre as características físico-químicas, sensoriais, microbiológicas e vida de prateleira. As formulações das massas foram, controle (F1), com extrato livre (F2) e com microcápsulas (F3), foram realizadas as análises de pH, atividade de água, cor, análise sensorial, microbiológica e vida de prateleira dos fenólicos por 28 dias. As massas cozidas contendo microcápsulas permaneceram com $25 \%$ de fenólicos até o $14^{\circ}$ dia e as massas cruas com $15 \%$ de fenólicos até o $21^{\circ}$ dia de armazenamento. As massas com microcápsulas mostraram boa aceitabilidade não diferindo da massa controle, entretanto as massas com o extrato livre mostraram menor aceitação em relação às demais. A adição das microcápsulas não alterou a parte microbiológica, pH, atividade de água e cor das massas.

Palavras-chave: análise sensorial, fenólicos, microcápsulas, cor.

\section{INTRODUCTION}

Soybean molasses is a by-product of soy protein concentrate that is manufactured for human consumption and is rich in bioactive compounds. The use of soybean molasses has economic advantages in that it involves the transformation of a by-product into a valuable product, thus contributing to the intake of bioactive compounds and commercialization by the food industry (SIQUEIRA et al., 2008).

The great challenge of the application of bioactive compounds in foods has led to various studies on microencapsulation techniques, leading to the spray drying method being considered one of the most economical and flexible processes available (SUNNY-ROBERTS \& KNORR, 2009). The microencapsulation process allows the core, which contains the encapsulated material, to be isolated from the external environment and, thereby, not interact with the food matrix, thus providing greater stability and allowing the release of compounds in optimized amounts across suitable periods (ROSA et al., 2018).

The growing search of the world population for foods that bring well-being and health benefits has motivated a series of studies on this subject (SKAROVANKOVA et al., 2015). The 
consumption of pasta is quite significant in Brazil, due to the tendency of consumers to look for practical and easily prepared foods. Both from a nutritional and economic point of view, pasta is an appropriate substrate for enrichment with functional ingredients (PAUCAR-MENACHO et al., 2008). In this context, this study produced pasta containing soybean molasses microparticles and to evaluate the effect of the microparticles on the physicochemical, sensory, and microbiological characteristics of the pasta, as well as the shelf life of the end product.

\section{MATERIALS AND METHODS}

\section{Preparation of extracts and microparticles}

Soybean molasses was provided from the Selecta industry (Goiania, GO). The extract was obtained using 50\% cereal alcohol at a sample/ solvent ratio of 1:10 (v/v), as described by CARR ÃOPANIZZI et al. (2002), with modifications. In this case, the extract was kept under constant agitation for 2 hours at room temperature $(250 \mathrm{rpm}$ on an orbital shaker, Tecnal TE140, São Paulo, Brazil), followed by centrifugation (Serilab MTD III Plus, São Paulo, Brazil) at $1083 \mathrm{~g}$ for $20 \mathrm{~min}$, thus obtaining two fractions: supernatant and precipitate. The supernatant was subjected to rotary evaporation and, subsequently, 100 $\mathrm{mL}$ of the evaporated extract (Buchi R-3, São Paulo, Brazil) was microencapsulated using a lab-scale mini spray dryer (Buchi B-290) with a $1.5 \mathrm{~mm}$ feed nozzle at a flow rate of $0.45 \mathrm{~L} / \mathrm{h}$. Hi-maize ${ }^{\circledR} 18 \%$ was used as the wall material at an inlet air temperature of $130{ }^{\circ} \mathrm{C}$.

The following formulations were prepared: control formulation $\mathrm{F} 1$, consisting of $130 \mathrm{~mL}$ water, $426 \mathrm{~g}$ wheat flour, $47 \mathrm{~g}$ egg, and $8 \mathrm{~g}$ salt; formulation F2, which contained the free extract, consisting of 90 $\mathrm{mL}$ water, $426 \mathrm{~g}$ wheat flour, $47 \mathrm{~g}$ egg, $8 \mathrm{~g}$ salt, and 40 $\mathrm{mL}$ free extract, corresponding to $66 \mathrm{mg}$ of total phenolics, and formulation $\mathrm{F} 3$, containing the microencapsulated extract, which consisted of $140 \mathrm{~mL}$ water, $386 \mathrm{~g}$ wheat flour, $47 \mathrm{~g}$ egg, $8 \mathrm{~g}$ salt, and $40 \mathrm{~g}$ microparticles with extract containing $60.56 \mathrm{mg}$ of phenolics.

The ingredients were mixed until obtaining a homogeneous dough, which was rolled and cut into noodles. Cooking was performed in 1:10 boiling water for $3 \mathrm{~min}$, which is the time required for the central axis to disappear, as was determined by compressing the pasta between two glass slides in $30 \mathrm{sec}$ intervals (AACC, 2000). The samples were packed in polyethylene packages and stored under refrigeration $\left(4^{\circ} \mathrm{C}\right)$. The stability of the pasta was evaluated by determining the loss of total phenolics after $1,7,14,21$, and 28 days of storage.
The phenolic compounds of the microparticles were determined via the FolinCiocalteu method, as described by SINGLETON et al. (1999), using a spectrophotometer (Biospectro modelo SP-220, São Paulo, Brazil) at wavelength $700 \mathrm{~nm}$. Results were expressed as gallic acid equivalents (mg GAE/100 g sample), which were calculated using the calibration curve, $\mathrm{Y}=0.0126 \mathrm{x}$ - 0.0004, $\mathrm{R}^{2}=0.9909$, that was constructed using a gallic acid standard at concentrations ranging from 0 to $100 \mu \mathrm{L} / \mathrm{mL}$. For the determination of phenolic compounds, $5 \mathrm{~g}$ of pasta was weighed and $50 \mathrm{~mL}$ of $50 \%$ cereal alcohol was added and homogenized at $700 \mathrm{rpm}$ at room temperature $\left(25^{\circ} \mathrm{C}\right)$. After complete homogenization, the samples were subjected to an ultrasound bath for $10 \mathrm{~min}$, centrifuged at $3000 \mathrm{rpm}$ for $10 \mathrm{~min}$, and then filtered.

The antioxidant capacity was determined by the ORAC (Oxygen Radical Absorbance Capacity) method, as described by OU et al. (2001), using a spetrophotometer (Biospectro modelo SP-220, São Paulo, Brazil) at wavelength $700 \mathrm{~nm}$, and the results were compared with a standard Trolox curve

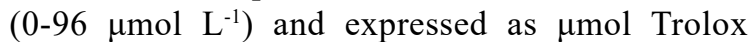
equivalents/g sample. The ORAC was calculated as follows:

$A U C=1+f 1 / f 0+f 2 / f 0+f 3 / f 0+\cdots f n / f 0$

where, f1...fn indicates the fluorescence determined every minute and f0 denotes the fluorescence at time zero.

The $\mathrm{pH}$ was measured using a previously calibrated (buffer solutions $\mathrm{pH} 4.0$ and 7.0) potentiometer (Digimed ${ }^{\circledR}$ DM-22, São Paulo, Brazil). For the determination of water activity (aw), an Aqualab $^{\circledR}$ 4TEV apparatus (Decagon Devices, Pullman, WA, USA) was used. The color was analyzed according to the CIELab system, measuring the parameters $\mathrm{L}^{*}, \mathrm{a}^{*}$, and $\mathrm{b}^{*}$, in which $\mathrm{L}^{*}$ determines the position of the point on the vertical axis of brightness, $\mathrm{a}^{*}$ indicates the point on the (-) green/red (+) axis, and $\mathrm{b}^{*}$ denotes the corresponding point on the blue/yellow $(+)$ axis (+), using the Minolta CR-300 colorimeter (Konica Minolta, Osaka, Japan, 1994).

The microbiological and physicochemical characterization of the fresh pasta was performed according to the methodologies of the Brazilian Normative Instruction \# 62, and Resolution RDC \# 12, respectively (BRAZIL, 2001).

The sensory evaluation of the samples was performed after 7 days of storage at $4 \pm 1{ }^{\circ} \mathrm{C}$. The pasta was cooked in salted cooking water, and 10 $\mathrm{g}$ of the sample was served in a monadic way on 
disposable white plates coded with random threedigit numbers; drinking water was also supplied for palate cleansing. One hundred untrained consumers, recruited at the Center of Rural Sciences at UFSM, participated in the sensory analysis. The affective test was used to evaluate the acceptance of the products (MONTEIRO, 1984) in terms of the attributes of color, odor, flavor, texture, and overall appearance, using a 7-point structured hedonic scale with the ends anchored by dislike very much (1) and liked very much (7).

Data were submitted to analysis of variance (ANOVA), followed by Tukey's test for comparison of means. Results were considered significant when $\mathrm{P}<0.05$. Statistical analyses were performed using STATISTICA version 7.0 (StatSoft Inc, Tulsa, OK, USA).

\section{RESULTS AND DISCUSSION}

Phenolic compounds in the free and microencapsulated soybean molasses extracts.

The total phenolic content in the free soybean molasses extract was $167.49 \pm 0.02 \mathrm{mg}$ GAE/100 g, and the antioxidant activity was 191.02 $\pm 0.96 \mu \mathrm{mol}$ Trolox $/ \mathrm{g}$. The microparticles exhibited $30.28 \pm 0.03 \mu \mathrm{mol}$ Trolox $/ \mathrm{g}$ and antioxidant activity of $90.03 \pm 0.17 \mu \mathrm{mol}$ Trolox $/ \mathrm{g}$, corresponding to the amount of extract used during the microencapsulation process, thus obtaining a total of $20 \mathrm{~g}$ of microparticles.

The microencapsulation resulted in retention of $20 \%$ of the phenolic compounds present in the initial extract, probably due to the high temperatures used in the spray drying process, as phenolic concentrations in soybean products have been shown to depend on the processing conditions, especially temperature (ZHANG et al., 2003). It is also noted that the antioxidant activity decreased with the microencapsulation process.

Although, the microencapsulation process led to a high degradation of bioactive compounds, use of Hi-maize ${ }^{\circledR}$ as an encapsulating agent allowed greater encapsulation efficiency, yielding $20 \mathrm{~g}$ capsules per $100 \mathrm{~mL}$ of encapsulated extract. Encapsulation efficiency is defined by the amount of compound trapped within the microcapsule and depends on the inlet air temperature, encapsulating agent, and the affinity between the encapsulating agent and the compound to be encapsulated, among other factors (KISSEL et al., 2006).

As shown in table 1, the $\mathrm{pH}$ of pasta gradually decreased during storage, while the water activity remained stable. Although, the phenolic content of both the raw pasta with free extract and with the microparticles decreased during storage, the pasta containing the microparticles exhibited higher phenolic levels at the end of the storage period. Similar behavior was observed for the cooked pasta, despite presenting higher phenolic losses after cooking. The phenolics content remained until the $14^{\text {th }}$ day of storage for both the pastas made with free extract and microparticles however, pasta containing the microparticles was more stable upon heating.

Table $1-\mathrm{pH}$, water activity, total phenolics of raw and cooked pasta during 21 days of refrigerated storage at $4{ }^{\circ} \mathrm{C}( \pm 1)$.

\begin{tabular}{|c|c|c|c|c|c|}
\hline \multicolumn{2}{|c|}{--------Fresh pasta-------- } & \multicolumn{3}{|c|}{----------------------------------------Raw--------------------------------- } & \multirow{2}{*}{$\begin{array}{c}\text { Cooked } \\
\text { Total phenolics mg GAE/100 g }\end{array}$} \\
\hline & & $\mathrm{pH}$ & Aw & Total phenolics mg GAE/100 g & \\
\hline \multirow{3}{*}{$1^{\circ}$ day } & F1 & $6.46^{\mathrm{A}} \pm 0.00$ & $0.96^{\mathrm{A}} \pm 0.00$ & $1.02^{\mathrm{Ga}} \pm 0.00$ & $0.85^{\mathrm{Ga}} \pm 0.01$ \\
\hline & $\mathrm{F} 2$ & $6.49^{\mathrm{A}} \pm 0.01$ & $0.97^{\mathrm{A}} \pm 0.00$ & $60.28^{\mathrm{Aa}} \pm 0.02$ & $35.09^{\mathrm{Bb}} \pm 0.02$ \\
\hline & F3 & $6.45^{\mathrm{A}} \pm 0.00$ & $0.96^{\mathrm{A}} \pm 0.00$ & $61.92^{\mathrm{Aa}} \pm 0.11$ & $42.66 \mathrm{~A}^{\mathrm{Ab}} \pm 0.01$ \\
\hline \multirow{3}{*}{$7^{\circ}$ day } & F1 & $6.18^{\mathrm{D}} \pm 0.01$ & $0.97^{\mathrm{A}} \pm 0.00$ & $0.91^{\mathrm{Ha}} \pm 0.01$ & $0.75^{\mathrm{Db}} \pm 0.02$ \\
\hline & $\mathrm{F} 2$ & $6.23^{\mathrm{C}} \pm 0.02$ & $0.96^{\mathrm{A}} \pm 0.00$ & $55.88^{\mathrm{Ba}} \pm 0.00$ & $22.18^{\mathrm{Db}} \pm 0.01$ \\
\hline & F3 & $6.33^{\mathrm{B}} \pm 0.01$ & $0.96^{\mathrm{A}} \pm 0.00$ & $61.60^{\mathrm{Aa}} \pm 0.01$ & $24.67^{\mathrm{Cb}} \pm 0.01$ \\
\hline \multirow{4}{*}{$14^{\circ}$ day } & F1 & $6.12^{\mathrm{E}} \pm 0.02$ & $0.96^{\mathrm{A}} \pm 0.00$ & $0.86^{\mathrm{Ia}} \pm 0.00$ & $0.43^{\mathrm{Hb}} \pm 0.01$ \\
\hline & $\mathrm{F} 2$ & $6.12^{\mathrm{E}} \pm 0.01$ & $0.96^{\mathrm{A}} \pm 0.00$ & $42.23^{\mathrm{Da}} \pm 0.00$ & $8.74^{\mathrm{Fb}} \pm 0.02$ \\
\hline & F3 & $6.10^{\mathrm{E}} \pm 0.01$ & $0.96^{\mathrm{A}} \pm 0.00$ & $45.14^{\mathrm{Ca}} \pm 0.01$ & $10.49^{\mathrm{Eb}} \pm 0.02$ \\
\hline & F1 & $6.05^{\mathrm{F}} \pm 0.01$ & $0.96^{\mathrm{A}} \pm 0.00$ & $0.45^{\mathrm{Ja}} \pm 0.02$ & $0.02^{\mathrm{Kb}} \pm 0.00$ \\
\hline \multirow[t]{2}{*}{$21^{\circ}$ day } & $\mathrm{F} 2$ & $6.05^{\mathrm{F}} \pm 0.02$ & $0.96^{\mathrm{A}} \pm 0.00$ & $8.23^{\mathrm{Fa}} \pm 0.02$ & $0.04^{\mathrm{Jb}} \pm 0.00$ \\
\hline & F3 & $6.06^{\mathrm{F}} \pm 0.01$ & $0.96^{\mathrm{A}} \pm 0.00$ & $11.08^{\mathrm{Ea}} \pm 0.01$ & $0.07^{\mathrm{Ib}} \pm 0.00$ \\
\hline
\end{tabular}

Results expressed as Mean $\pm \mathrm{SD}(\mathrm{n}=3)^{\mathrm{AB}}$ Equal capital letters in the same column show no significant difference by Tukey's test ( $\mathrm{P}$

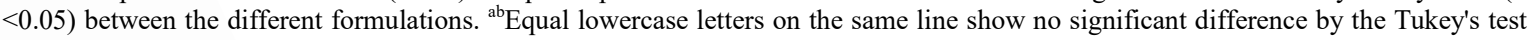
$(\mathrm{P}<0.05)$ between the same formulations and day of storage. 
The concentration of phenolic compounds in both the cooked pasta made with free extract and that containing microparticles was $25 \%$ until the $14^{\text {th }}$ day of storage. Meanwhile, the raw pasta exhibited $15 \%$ of original phenolic content until the $21^{\text {st }}$ day of storage. Importantly, pasta made with the free extract presented phenolic content up to 21 days of storage, presumably due to both the refrigerated storage and the high antioxidant activity of the extract. The determination of phenolic compounds was not performed at 28 days of storage, at which time the pasta was cooked for consumption, and the cooked pasta in the present study presented very low contents of these compounds after only 21 days of storage.

Regarding the color variable $\mathrm{L}^{*}$, values ranged from 78.49 to 57.69 in the various pasta formulations (Table 2), with a darkening observed during storage. However, after 14 days, the pasta made with free extract (F2) presented higher luminosity than the pasta made with the microparticles, probably due to the high antioxidant activity of the extract. The darker coloration of the pasta may be due to the natural colors of Hi-maize and soybean molasses, which are darker $\left(\mathrm{L}^{*} 52.63\right)$.

The color coordinate $b^{*}$, which varies from blue to yellow, decreased on the $7^{\text {th }}$ day of storage for all formulations, with no significant differences observed between formulations until the end of storage, indicating that the pasta did not undergo oxidation. The values presented in the current study are lower than the values observed by PAUCARMENACHO et al. (2008), who reported b* values of 28.41 in functional fresh pasta made with different concentrations of soy protein isolate and polydextrose.

Regarding the color coordinate $\mathrm{a}^{*}$, no significant differences were observed during storage for across all formulations, with values remaining stable for 21 days. The coordinate $\mathrm{a}^{*}$ represents the red color and is a good indicator of color stability (RAMOS \& GOMIDE, 2007).

Concerning the microbiological characterization of the different pasta formulations, all cases exhibited Bacillus cereus counts $<1.0 \times 10^{1}$, coliforms at $45^{\circ} \mathrm{C}<3.0 \mathrm{NMP} / \mathrm{g}$, absence of Salmonella, and coagulase-positive staphylococci $<1.0 \times 10^{2}$. According to the Resolution 12 of the Brazilian National Health Regulatory Agency (ANVISA, Brazil, 2001), which established microbiological criteria for food, the fresh pasta is within required standards, with maximum acceptable limits being $10^{2} \mathrm{CFU} / \mathrm{g}$ for coliforms at 45 ${ }^{\circ} \mathrm{C}, 5 \times 10^{3} \mathrm{CFU} / \mathrm{g}$ for coagulase-positive staphylococci, $5 \times 10^{2} \mathrm{CFU} / \mathrm{g}$ for Bacillus cereus, and the absence of Salmonella sp. in $25 \mathrm{~g}$ of the sample. Concerning the coliforms at $35^{\circ} \mathrm{C}$, the counts were $9 \times 10^{2}, 9 \times 10^{1}$, and $4 \times 10^{3}$ $\mathrm{NMP} / \mathrm{mL}$ for the control, the formulation containing the microparticles, and the formulation containing the free extract, respectively. The counts of coliforms at $45^{\circ} \mathrm{C}$ were below $10^{1} \mathrm{CFU} / \mathrm{g}$ for all fresh pasta formulations.

As shown in table 3, there was no significant difference in consumer acceptance of the

Table 2 - Color of fresh pasta after the addition of free extract and microencapsulated soybean molasses extract during 21 days of storage at $4{ }^{\circ} \mathrm{C}( \pm 1)$.

\begin{tabular}{|c|c|c|c|c|}
\hline \multirow[t]{2}{*}{ Days of storage } & \multirow[t]{2}{*}{ Fresh pasta formulations } & \multicolumn{3}{|c|}{ 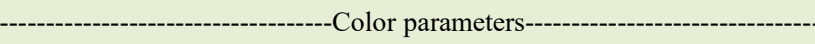 } \\
\hline & & $\mathrm{L}^{*}$ & $\mathrm{a}^{*}$ & $\mathrm{~b}^{*}$ \\
\hline \multirow{3}{*}{$1^{\circ}$ day } & F1 & $78.49^{\mathrm{Aa}} \pm 1.10$ & $7.18^{\mathrm{Ca}} \pm 0.51$ & $21.53^{\mathrm{Ba}} \pm 0.83$ \\
\hline & $\mathrm{F} 2$ & $71.87^{\mathrm{Ca}} \pm 0.44$ & $8.09^{\mathrm{Ba}} \pm 0.11$ & $23.43^{\mathrm{Aa}} \pm 0.13$ \\
\hline & F3 & $73.21^{\mathrm{Ba}} \pm 1.11$ & $10.01^{\mathrm{Aa}} \pm 0.26$ & $23.28^{\mathrm{Aa}} \pm 0.33$ \\
\hline \multirow{3}{*}{$7^{\circ}$ day } & $\mathrm{F} 1$ & $74.10^{\mathrm{Ab}} \pm 0.72$ & $6.88^{\mathrm{Ba}} \pm 0.18$ & $18.45^{\mathrm{Bb}} \pm 0.16$ \\
\hline & $\mathrm{F} 2$ & $69.39^{\mathrm{Cb}} \pm 0.70$ & $8.59^{\mathrm{Aa}} \pm 0.23$ & $21.99^{\mathrm{Ab}} \pm 0.38$ \\
\hline & F3 & $70.49^{\mathrm{Bb}} \pm 0.51$ & $8.97^{\mathrm{Aa}} \pm 0.13$ & $22.05^{\mathrm{Ab}} \pm 0.63$ \\
\hline \multirow{3}{*}{$14^{\circ}$ day } & $\mathrm{F} 1$ & $72.94^{\mathrm{Ac}} \pm 0.22$ & $7.40^{\mathrm{Ca}} \pm 0.21$ & $18.20^{\mathrm{Bb}} \pm 0.19$ \\
\hline & $\mathrm{F} 2$ & $62.94^{\mathrm{Bc}} \pm 1.83$ & $8.99^{\mathrm{Ba}} \pm 0.03$ & $22.29^{\mathrm{Aab}} \pm 0.19$ \\
\hline & F3 & $60.83^{\mathrm{Cc}} \pm 1.07$ & $9.66^{\mathrm{Aa}} \pm 0.19$ & $22.83^{\mathrm{Aab}} \pm 0.78$ \\
\hline \multirow{3}{*}{$21^{\circ}$ day } & $\mathrm{F} 1$ & $70.08^{\mathrm{Ad}} \pm 0.21$ & $8.09^{\mathrm{Ca}} \pm 0.19$ & $18.09^{\mathrm{Bb}} \pm 0.18$ \\
\hline & $\mathrm{F} 2$ & $60.23^{\mathrm{Bd}} \pm 0,23$ & $9.13^{\mathrm{Ba}} \pm 0.05$ & $21.18^{\mathrm{Abc}} \pm 0.18$ \\
\hline & $\mathrm{F} 3$ & $57.69^{\mathrm{Cd}} \pm 0,88$ & $9.55^{\mathrm{Aa}} \pm 0.17$ & $22.27^{\mathrm{Aab}} \pm 0.73$ \\
\hline \multicolumn{2}{|c|}{---------------------------------Extract-------------------------- } & $52.63^{\mathrm{D}} \pm 0.12^{\mathrm{d}}$ & $3.10^{\mathrm{D}} \pm 0.33$ & $9.37^{\mathrm{C}} \pm 0.14$ \\
\hline
\end{tabular}

Results expressed as Mean $\pm \mathrm{SD}(\mathrm{n}=3){ }^{\mathrm{AB}}$ Equal capital letters in the same column show no significant difference by Tukey's test (P $<0.05)$ between the different formulations. ${ }^{\text {ab }}$ Equal lowercase letters on the same line show no significant difference by the Tukey's test $(\mathrm{P}<0.05)$ between the same formulations and day of storage. 
Table 3 - Acceptance test of different fresh pasta formulations.

\begin{tabular}{lcrr}
\hline Attributes & & & \\
& & & \\
& & & \\
& & & \\
Color & $4.92^{\mathrm{a}} \pm 0.92$ & $4.49^{\mathrm{b}} \pm 1.03$ & $5.02^{\mathrm{a}} \pm 0.98$ \\
Odor & $4.93^{\mathrm{a}} \pm 1.02$ & $4.87^{\mathrm{a}} \pm 1.06$ & $4.91^{\mathrm{a}} \pm 0.96$ \\
Flavor & $5.18^{\mathrm{a}} \pm 1.38$ & $4.67^{\mathrm{b}} \pm 1.12$ & $5.07^{\mathrm{a}} \pm 1.02$ \\
Texture & $5.22^{\mathrm{a}} \pm 1.13$ & $5.16^{\mathrm{a}} \pm 1.26$ & $5.29^{\mathrm{a}} \pm 1.01$ \\
Appearance & $5.29^{\mathrm{a}} \pm 1.08$ & $4.73^{\mathrm{b}} \pm 0.89$ & $5.16^{\mathrm{a}} \pm 1.02$ \\
\hline
\end{tabular}

Results expressed as Mean $\pm \mathrm{SD}(\mathrm{n}=3)^{\text {ab }}$ Equal lowercase letters on the same line show no significant difference by Tukey's test (P $<0.05$ ). Control formulation (F1); Formulation containing free extract (F2); Formulation containing microencapsulated extract (F3). Scores: $1=$ extremely disliked; $2=$ moderately disliked; $3=$ disliked; $4=$ indifferent; $5=1$ liked; $6=$ liked very much; $7=$ extremely liked.

pasta made with the microparticles when compared to the control, with scores ranging between "liked" and "liked very much" for the attributes of flavor, texture, and appearance, thus demonstrating good acceptability. However, the pasta made with free extract (F2) was less accepted when compared to the other formulations, due to the dark color of the soybean molasses extract, which made the pasta appear darker, as well as its strong off-flavor.

\section{CONCLUSION}

Pasta made with free extract and raw and cooked pasta containing the microparticles all exhibited losses of phenolic compounds during storage. However, cooked pasta made with either free extract or microparticles both retained $25 \%$ of their original phenolic content up to the $14^{\text {th }}$ day of storage, while raw pasta exhibited $15 \%$ original phenolic content until 21 days of storage. Although, good sensory acceptability was observed for pasta containing the microparticles, with no differences from the control, pasta made with the free extract was less accepted than the others. No changes in $\mathrm{pH}$, water activity, or color were observed for pasta made with the addition of soybean molasses microparticles.

\section{ACKNOWLEDGEMENTS}

Coordenação de Aperfeiçoamento de Pessoal de Nível Superior (CAPES), Brasil - Finance code 001.

\section{DECLARATION OF CONFLICT OF INTEREST}

The authors declare no conflict of interest. The founding sponsors had no role in the design of the study; in the collection, analyses, or interpretation of data; in the writing of the manuscript, and in the decision to publish the results.

\section{AUTHORS' COTRIBUTIONS}

The authors contributed equally to the manuscript.

\section{REFERENCES}

AMERICAN ASSOCIATION OF CEREAL CHEMISTS. (2000). Approv. Meth. (10 ed). Saint Paul: AACC 2000.

BRASIL. Agência Nacional de Vigilância Sanitária. Instrução Normativa $\mathrm{n}^{\mathrm{o}} 12$, de 02 de janeiro de 2001. Dispõe de regulamento técnico sobre os padrões microbiológicos para alimentos. Brasília, 2001. Available from: <https:// http://portal.anvisa.gov.br/ documents/33880/2568070/RDC_12_2001.pdf/15ffddf6-37674527-bfac-740a0400829b>. Accessed: Jul. 12, 2019.

CARRÃO-PANIZZI，M. C., AHEN COMPAL. Enviromental and genetic variation of isoflavones content of soybean seeds grown in Brazil. Pesquisa Agropecuária Brasileira, v.44, n.11, p.1444-1451, 2002. Available from: <http://www.scielo.br/scielo. php?script $=$ sci_arttext\&pid $=$ S0 100-204X2009001100011>. Acessed: Jan. 15, 2018. doi: 10.1590/S0100-204X2009001100011.

KISSEL, T., et al. Microencapsulation tecniques for parental depot systems and their application in the pharmaceutical industry. Benita, S. Microencapsulation: Meth. and Ind. Aplic.. $2^{\circ}$ edição. Boca Raton, CRC, Press Taylor e Francis Group, v.4, p.104, 2006. Available from: <https://www.taylorfrancis.com/books/ microencapsulation-simon-benita/10.1201/9781420027990>. Accessed: Apr. 05, 2018. doi: 10.1201/9781420027990.

OU, B., et al. Development and validation of na improved oxygen radical absorbance capacity assay using fluorescein as the fluorescente. Jour. of Agric. and Food Chem., v.49, n. 10, p.46194629, 2001. Available from: <https://pubs.acs.org/doi/10.1021/ jf010586o $>$. Accessed: Nov. 18, 2017. doi: 10.1021/jf010586o.

PAUCAR-MENACO, L. M., et al. Development of functional fresh food adding soy protein isolate and polidextrose using paprika as coloring agente. Food Scien. And Techn., v.28, n.4, p.767-778, 2008. Available from: <https://www.scielo.br/scielo. 
php pid $=$ S0101-20612008000400002\&script $=$ sci_abstract $>$. Accessed:Apr. 23, 2018. doi: 10.1590/S0101-20612008000400002.

ROSA, D. R. J., et al. Microencapsulation of anthocyanin compounds extracted from blueberry (Vaccinium spp.) by spray drying: characterization, stability and simulated gastrointestinal conditions. Food Hydr., v.89, p.742-748, 2018. Available from: <https://www.sciencedirect.com/science/article/abs/pii/ S0268005X18313778?via\%3Dihub > . Accessed: Jul. 23, 2020. doi: 10.1016/j.foodhyd.2018.11.042.

SINGLETON, V. L., et al. Analysis of toal phenols and other oxidation substrates and antioxidants by means of Folin-ciocalteu reagente. Meth. of Enzym., v.299, p.152-178, 1999. Available from: $\quad<$ https://www.sciencedirect.com/science/article/pii/ S0076687999990171>. Accessed: May, 23, 2019. doi: 10.1016/ S0076-6879(99)99017-1.

SIQUEIRA P. F. et al. Production of bioethanol from soybean molasses by Saccharomyces cerevisiae at laboratory, pilot and industrial scales. Biores. Technol., v.99, p.8156-8163, 2008. Available from: <https://www.academia.edu/23344536/
Production_of_bio_ethanol_from_soybean_molasses_by_ Saccharomyces_cerevisiae_at_laboratory_pilot_and_industrial scales>.Accessed:Aug. 17, 2018. doi: 10.1016/j.biortech.2008.03.037.

SKAROVANKOVA, S., et al. Different types of berries. Intern. Jour. Of. Mol. Scien., v.16, p.2463-24706, 2015. Available from: $\quad<$ http://www.mdpi.com/1422-0067/16/10/24673/htm\#>. Accessed: Dec. 20, 2017. doi: 10.3390/ijms161024673.

SUNNY-ROBERTS, E. O., KNORR, D. The protective effect of monosodium glutamate on survival of Lactobacillus rhamnosus GG and Lactobacillus rhamnosus E-97800 (E800) strains during spray-drying and storage in trehalose-containing powders. Int. Dair Jour., v.19, p.209-214, 2009. Available from: <https://www.sciencedirect.com/science/article/abs/pii/ S0958694608001933/>. Accessed: Jan. 18, 2019. doi: 10.1016/j. idairyj.2008.10.008.

ZHANG, Y. C., et al., Isoflavone profile and biological activity of soy bread. J. Agric. Food Chem., v.51, p.7611-7616, 2003. Available from: <https://pubmed.ncbi.nlm.nih.gov/14664516/>. Accessed: Apr. 20, 2019. doi: 10.1021/jf034679c. 